\title{
The Bog: A Naturalist's Notebook •
}

R. H.W. Dillard

\begin{abstract}
The ideal scientific mind ... should be capable of thinking out a point of abstract knowledge in the interval between its owner falling from a balloon and reaching the earth.
\end{abstract}

- George E. Challenger

THIS NOTEBOOK is the property of C. Cotswaldo, Ph.D., and should be promptly returned if and when found to the Institute of Theoretical Studies, Room 18, Desk 5/9. I shall be happy to pay a suitable reward, and I should add that the contents of this notebook will be of no use or interest to you, although they are of extreme value to me.

Thank you.

Sink or swim, here I am. The Institute of Theoretical Studies with its odd acronym ITS, a gathering of rectangular buildings, relatively windowless, almost medieval in its defensive stance toward the surrounding natural world, fully air conditioned against the sultry summer which is encamped around it with the surrounding forest, the low stagnant bog, even the distant hazy blue mountains, an ice cube of ideas afloat in a soup of steaming reality. An appropriate place for me, or so I feel, in more ways than one. Have been here over a week, have overcome my initial awe and the usual sense of spatial/temporal displacement which I always feel in a new place. Have settled in at my desk in the yellow cube which is, for the time, mine (yellow a stimulant to thought according to the psychic designer who did the ITS buildings, although I remember that it often rouses schizophrenics to split and shatter like bits of fossilized shale). Have explored the woods, many paths, the edges of the large bog tracked by the lanes of egg-heavy female turtles heading for their destinies. Am, in other words, at home.

But, this notebook: I have realized that if I am to use my time, organize my thinking, aim it toward a new book, I'll need to follow the lead of my New England forebears, E \& T, and keep a journal of sorts, a grab bag of sensations and ideas from which, with some diligence and 
a little bit of luck, I can gather the data for the new book relatively whole and not have to start from raw scratch as I did with Darwin's Bassoon. Thus, here I'll put into the best prose I can the events that strike me as grist for my grinders, the day's events, memories, quotations, citations, cetera cetera.

The drive to ITS winds through the low mountains, scruffy around the collar with edgy pine and alien kudzu, the road narrow and ridgey at the bends, coiling away from the interstate and the airport, the hum and buzz, the daily variety, into a nature lacking in the sublime but making up for it with a primitive urgency. A deer looks steadily at you from the side of the road, a black runner slides across the gravel and tar like a stream of spilled mercury, an eagle (buzzard?) soars on an updraft up and away. The wild, mindless, energy without end (endless and purposeless), a ragged world running on its aimless way, a machine woünd up so long ago that its Prime Winder has long since forgotten that He ever touched the stem and set it blindly ticking.

You look closer and you see death in this wilderness: a groundhog, yellow teeth, the bushy tail flat and rotten, sinking back into the soil, feet up, back first; trees broken and ruined, tent caterpillars settled in the sick branches like bedouin tribes (hippies?) riding the dead tree down; a rabbit torn open and mashed on the road by the tire of an ITS scholar doubtless, his mind focussed on the stars as his wheel crushes the round inoffensive bunny head into the rock and stone; withered blackberries unpicked, uneaten on the dry stems, dry and hard and unfertile; a dogwood smothering in sweet honeysuckle, the pale small yellow blooms, the vines twining like a baby's fingers around the branches, the frail tree sinking in its odorous, female clutches, perfumed and soft and grasping.

Even the stone is eaten away by air and water, the rootlets of wild flowers, the sledge hammers of man. It is dizzying, all this death, this mindless life and death.

And it is our fault, our fault. Bearers of the watch key, given the power to twist the very stem of life, we live instead in this mindless nightmare. Samuel Butler was right when he said that Darwin had banished "mind from the universe," and I have discussed the reasons for that banishment in Darwin's Bassoon. Mad reasons with mad results. And now my task: to restore mind to the universe!!! 
I keep wanting to rush ahead: from the road to ITS to the cosmos, from the problem to the solution with no intermediate steps. I must settle back like a wise toad, tongue poised, wait for the fat foolish green flies. Describe plainly and simply. Lie in wait in my stalker's blind.

\section{Myself:}

My name is Cosmo Cotswaldo. I write under the name C. Cotswaldo, for the obvious reason. I have always hated my name. Usually I give my first name as Charles. I call myself Chuck, have since I was old enough to impose my wishes on the world around me.

Thirty-seven years old, I am a full Professor of Philosophy, albeit at Albert University, no Cambridge or Harvard, a school primarily renowned for its Education Department and its experimental use of candy as positive reinforcement, as an incentive to learning in higher as well as lower education - the Butterfingers System, as it came to be known around the land.

How many embarrassed hours have I spent offering senior majors Clark bars or Baby Ruths for a particularly apt discussion of the Dasein or the Dissimilarity of the Diverse? Albert professors are always easily identifiable by the sagging pockets of their tweed jackets, those pockets distorted not with pipe or shag tobacco, but candy kisses and Necco wafers. My teeth are riddled with the silvery residue of absent-minded munching; my belly is soft with eager cells permanently awaiting fresh infusions of sugary fat. I still find Zero bars and boxes of Boston Baked Beans in my pockets here at ITS; in fact, I feel almost inadequate without the familiar weight and fill my pockets every morning in some sort of ritualistic communion with my daily Albert life.

Why I should feel the need for this grounding in Albert is beyond me. The same reason flowers blossom better where cows have paused, I suspect. The rest of my department is composed of a collection of aging hacks or incompetent young ABD's inscribing syllogistic circles on chalkdusty blackboards of the old classrooms or engaging in eggy arguments with bright-eyed undergraduates on the nature of love in Plato in what they proudly, if inaccurately, call seminars. But I suppose they do no great harm, juggling ideas like red balls in a burlesque act, occasionally rousing some alert student to strive for greater things. Albert is blessed with tenure, and despite their reluctance to recognize my light (only partially hidden under the bushel of obscurity), they have offered me a home. 
But, more of my background:

My undergraduate years were spent at a small college aptly named Wampum State (the Wampum Warriors bravely succumbing on the playing fields each weekend as were the Wampum maidens under every bush and shrub). I majored in philosophy despite my desire to become a biologist; the biology department seemed able only to metamorphose frightened cats into stiff packages of skin, fur and skewered guts as they all the while mouthed the pages of the textbooks and looked out the windows of the labs toward the distant golf courses. I hated them and their aimless cruelty, their foetal pigs and vivesected turtles (a string signalling each sad heartbeat through a ragged vent cut in their belly plates), their frogs, their pain and death, pain and death, pain and death.

I was, then, a philosophy major, able to think about nature without being forced to torture it. I wanted to do a thesis on Thoreau's horror of the inanimate, but was steered into a prize winning one on "Moral Implications of Overcrowding as Exemplified by Desmond Morris's Homosexualization of Ten Spined Sticklebacks." The chairman of the department was an ethics man; I needed the Phil Club prize to help me get a fellowship for graduate school.

I went on to Pennsylvania Commonwealth University. There I lost my innocence in more ways than one: to a remarkably thin, greasy haired waitress (who looked about thirty but was reputed to be sweet sixteen) who worked behind the counter at the College Inn and who would duck down behind that counter and initiate the newcomers with such a deadly seriousness that the young men (mostly freshmen) seldom even blushed as they stood there in plain view from the waist up, slapping idly at the counter with a damp dishcloth which she always kept at hand; and to my advisor in the Philosophy Department, Thorless Turnbull, who gave an annual lecture to the graduate students called, "On Being a Hunting Tiger in the Academic Jungle," and who advised me not to attempt to advance human knowledge ("Who needs or will pay for more human wisdom?") but rather to attach myself with parasitic intensity to some little known or read philosopher with some potential for discovery or rediscovery and, once hitched, wait for his star to rise.

Now that I look back on it, both waitress and old professor have much in common, both pale and unhealthy, both attended by long lines of yearning youths, both supplying an ugly release with little variety from day to day but with a great and unswerving steadiness, both of them 
rousing in me a deep and nearly despairing cynicism, a hatred of life so fierce as to almost drive me into the behavioristic clutches of the university psychology department's aberrant experimentation clinic.

Almost, but not quite. I adjusted. I survived. I did my master's thesis under Professor Luther Hagins, whose sole joy seemed to reside in his tidy shelves of collected copies of The Popular Science Monthly, so naturally and practically enough my thesis concerned certain aspects of secondness in Peirce. And I extended my experience into the usual neckings and gropings with the few female graduate students (always, therefore, in demand), who seemed always to be drunk at the time but nevertheless always wanting to discuss causality between kisses or belligerently insisting that I defend the doctrine of determining correspondence while striving the while to get my shirt unbuttoned or my scuffed sneakers off.

I produced a dissertation entitled "A Critical Analysis of the Loving Self in J. M. E. McTaggart." Yes, James McTaggart Ellis McTaggart, whose star, despite Broad's extensive (if negative) work, refuses to this day to climb too high in the philosphical sky. No excited university press scooped the dissertation up, although it travelled patiently from Cambridge U. to South Alabama, and it still sits (I assume) in its shiny black binder on a dusty back shelf in the university library in Gibbsville, $\mathrm{Pa}$.

I took a position at Albert, climbed to Assistant Professor quickly enough, buoyed by the paperback edition of H. G. Wells' Anticipations of the Reaction of Mechanical and Scientific Progress upon Human Life and Thought for which I supplied an introduction for College Classics, a reprint house which hovered always on the edge of the 56 year copyright expiration date, swooping down on those titles just venturing out into the public domain with the alertness and rapacity of a turkey vulture, paying the authors or their estates nothing and the introducers (all, it seems, assistant professors or stale desperate associates) in copies (ten, free; twenty, at a fifty percent discount). And there I stagnated for seven years, candy melting in my clutched hand, my day built around my daily trip to my post office box to see whether some lightning had struck even in the cloudless sky of my professional horizon.

And then came Darwin's Bassoon. My thunderclap.

Talking with Cortapiedras today. Learned some important things. I suppose I should try to describe him, describe ITS. Now while my thinking is focussed on the place and the society here. 
You enter ITS by way of a long curving drive which leads from the narrow mountain highway through two brick pillars appropriately inscribed, the road swinging in a slow even arc up a rounded hill (really a knoll), the grass clipped smooth and kept green by dint of watering and feeding, cedars and spruce scattered over the lawn, a pleasant, even-looking place, clearly a place designed to soothe rather than distract the mind. The buildings (six of them) are rectangular and brick with little glass.

Oh, this doesn't matter. Should try to describe them later, and the woods, the paths, the bog. Essential that a reader feel the place, the cool, indirect lighting of ITS, the hum of the air conditioning, the quiet in the halls, the mathematicians sitting slumped before their blackboards (green, of course) for hours on end, not even looking at the problem they've chalked up, staring at wall or floor or out the door (you pass like a wisp, a ghost, insubstantial in that unwavering gaze), and how occasionally with a burst and clatter they bound up, erase one number or slash with a sleeve and replace it with another, then back down and enter that abstract formal world of absolute meaning again.

Describe that and contrast it with the weedy paths, the unkempt woods, the rabbits flashing into brambles, the shuffling groundhogs, the bloated pale hairless floating (sinking?) thing in the bog, four swollen legs poked up at the sky, so repulsive and formless that I could never figure what it was, could not even try. The burgeoning life everywhere, the spider webs that cling to your face invisibly, the spider scurrying down your sleeve, that profusion of shivering, bulging, creeping, growing, growing, growing life, plant and animal, insect and humming air.

Describe them both, ITS and outside. Then the problem will come clear: how to join ITS to outs(ide), how to take that mathematical clarity, that meaning and infuse it into that whirling confusion outside, how to restore mind to matter.

But, now, to Cortapiedras, to our conversation. I lack the strength or purity of mind to describe those things now. He has given me much else to think about.

Juan Cortapiedras, the geologist, the geode man, whose studies of stone have pressed mind deeper into the inanimate than almost anyone before him. I have always stood in awe of his work, was even afraid to speak to him when I was introduced my first day by Horace Dolgrum, the director of ITS, the stern administrator. But Cortapiedras, the man at ease, not the mind at work, is an easy-going fellow, small, olive 
skinned, black hair, brown eyes, always smiling, red shirts and yellow trousers (in his yellow study he must be a sight indeed-maybe it is all that gray stone he works with). He promised to put me in touch with Langdon-Davies whose studies with peasant ESP would be of definite use to my work, and he has always been friendly, but only today has he become personal.

"Women," he began, grabbing my left elbow, squeezing it as he spoke, the electricity of his intense emotion actually causing my whole arm to shake (vibrate?) with its force, "What this place needs is women." And before I could reply, he continued, "God, some days, looking at all the beards and pipes and goddamn corduroys around this dump, I could piss on the floor I want a woman so bad. You feel it, you know, you do, yes. Jesus, a woman, one hot woman, call her research assistant, research ass, yes, you see? One woman," his clutch got even tighter, "I can tell, you are a man, too, not just a ball-less mental think-think. Oh for one good lay, yes? One hundred miles from the nearest woman, oh holy hell," here he clutched his crotch with his free hand, "how we supposed to make progress when all I can think of is women, huh? Yes, you see? You know."

I almost felt raped, almost fell over when he let my arm go, but then he continued, "But that old bastard Dolgrum, he goes into town today to bring a new research fellow back from the airport. Sure, I'll bet, sure, he goes to get his ashes shifted, I tell you."

"New fellow?" I tried to change the subject.

"Biologist," his intensity waned, he slumped back in his chair (we were in the snack bar, drinking iced tea). "Ethologist." Then, his interest quickening again, he added, "Maybe it's a woman, eh? Hot piece, nature lover type, huh? Yes."

Then he got up, walked away, his stride a curious scrabbling gait, almost sideways like a brightly colored crab. No word of parting. I sat there stunned, a complex of emotions swirling in me that I had not felt since leaving Albert.

It is, I suppose, important to say that I am not married. I lived with a woman, a linguist, for two years. Ostensibly in adjoining apartments, but I slept in her bed every night. She satisfied me sexually, cut my hair, criticized my work, nagged at my clothes, demanded that I take her dancing, the usual. I assume I offered her about as much pleasure as she did me. We talked. We screwed. No, I have to find a way to say all this, to indicate that I am normally male, no chauvinist or feminist. Prey to human needs. Not a loner. Must find a voice for this section. 
She left, went on to another job. I kissed her on the cheek at the airport. I still find bits of her hair on my suits, scraps of underwear or hairpins in my drawers. I have come to realize that she meant little to me, that I satisfied certain nest building needs of hers (sexual, social, even intellectual as she tidied up my prose), that she satisfied certain territorial needs of mine (dominance, sexual, social, so on).

I have never married. I have had few liaisons with students. Somehow it is no pleasure to me to seduce a young woman by praising her analysis of the infinite divisibility of particulars. Besides that, they have mothers and fathers (seldom still married to each other) and big brothers. So I live alone and look the other way when they cross their legs on the front row of class or lean across the desk with unbuttoned blouses, delivering their papers or accepting their candy bars.

So what, then, are these emotions that Cortapiedras has roused in me? They are not, I'm reasonably sure, mine. I seriously believe that they are his feelings, purely his, transmitted to me by the force of his utterance, the very grip of his fingers, cell to cell, his lust short circuiting the normal electrical business of my own cellular structure, racing through me like a wild current through a line without proper resistance. I must talk to him when he is this way again. Or, and this way I gain something like an experimental control, when he is that excited, to impose my own thinking on him, to cool him down with a burst of sheer mental clarity, to focus my sense of meaning in such a way as to force his sexual energy into a creative channel. The breakthrough in geological thought might be enormous. And I will be prepared. I won't allow the force of his lust to surprise me, to drive me to my bedroom, to shame me into that kind of behavior again.

Am writing this on a low bank by a sagging willow tree poised on the edge of the large bog which stretches over about three acres at the foot of the hill upon which ITS stands. You make your way down here along narrow, weedy paths. Occasionally the institute sends a man and a power mower along all of the paths, but his trips are few. The woods are second growth but fairly old. The trees stand on the average some thirty feet or better, but there is undergrowth, kudzu mad and rapacious, May apples, poison oak and ivy, jewel weeds with their seed ready to spring forth like tiny animals at the slightest touch, the thin green coils whirling in your palm, the small brown seed spinning out into the soil.

You see rabbits and groundhogs, at night opossums, lumbering and 
gray whiskered. I have seen and heard (and felt) the slick departure of snakes, but I have not yet seen one, have no idea whether they are black snakes or runners, corn or hog, or maybe even the cottonmouth moccasins that Lew Dark, the institute herpetologist, warned me about, lurking in the bog waters, ready to sear your veins with their needle fangs.

Mainly here, by the bog, where I plan to come often to write these notes, closer to my problem than I can ever be in my yellow study, I see frogs, bulging along under the bog slime like green moles, urping and skittering into the water at my every move. I enjoy their awareness of me. We are in communion whether they like it or not, and I plan to focus myself into them soon, to attempt intercellular communication with their whole beings, to impose my mind into their random behavior, to (using Koestler's brilliant metaphor) fill their froggy machines with my own ghost, to add mind to their sleek scared matter.

Deeper out, beyond the frogs, the bog seems to thicken, its green scum cover giving way to a deeper brown. Dark tells me that is quicksand and warns me to stay out of it. He lost a dog, a valuable mastiff named Moe, to this bog, this big beast swimming out after a stick, then sinking, slowly, horribly while Dark raced frantically around, trying to get a pole, a fallen tree, something long enough to reach the animal. But the dog struggled furiously and sank, could not understand that it would sink infinitely more slowly if it remained still, another victim of mindlessness, of the absurd world we have allowed ourselves to inhabit for so long with so little real effort to educate it, to bring it to consciousness. Poor Moe, woofing down into the deadly quicksand, clawing only at death with his poor paws, running down into the smothering, filling bog. Perhaps I will avenge you, quicken that dead sand to bring forth something alive rather than swallow everything whole. I shall certainly try. I shall surely try.

Myself (cont'd.):

Four years ago, bored by my job, my life, almost literally to death (to actual tears too often to mention), sinking in survey histories of western thought and lengthy essays at Boolean algebra, I took a year's leave at half pay and produced a small book, as much for my own amusement as anything else, a book venting my emotional overload by attacking Darwin's approach to evolution and assessing its impact on modern life.

Darwin's Bassoon, much to my surprise and certainly to that of my stunned colleagues at Albert, was immediately accepted by a small but 
very respectable New York publisher and became a best seller. It was an alternate selection of the Book-of-the-Month Club, a regular selection of the Occult Book Society, and a mass trade paperback special with a puzzling introduction by Erich von Däniken, all this within one year. It was distributed free to all associate members of the Natural History Museum, and it was nominated for a National Book Award (although it lost out to Matthew Hooper's personal narrative of shark attacks).

I became something of an overnight cult figure, acquired an unlisted phone number, a tax accountant and a bright red Alfa Romeo. I was promoted in succeeding years to Associate and then full Professor (ending for good and all my tenure nerves), attracted the sudden romantic attention of at least six attractive and inventive coeds from Albert and three other nearby universities and colleges, had the locks on my doors changed twice, and was invited to be a fellow at ITS (working on intercellular communication and its philosophical implications) for this summer.

I suppose I should include at least a brief account of the thesis of Darwin's Bassoon for those unacquainted with Masterplots.

I had always been concerned about Darwin and Darwinism, the blighted world he left us, allowing us to be victimized by Marx and Freud, left like corpses from the second of our births to the clacking jaws of the vultures of materialism, reductionism, absurdity and despair. Then I read Donald Fleming's penetrating essay, "Charles Darwin, the Anaesthetic Man," in Victorian Studies and realized for the first time that he was his own chief victim, that he turned away from all aesthetic experience in order to avoid the vision of beauty and harmony and meaning which he had, almost single-handedly, destroyed. His disavowal of the delights of art and music and all literature save those sickly sweet Victorian novels of family sentiment is clearly the act of a madman, a man so fearful of the power of his imagination that he attempts to stifle it utterly.

I began to study Darwin's life and writings with some thoroughness and arrived at the conclusion that, although he was undoubtedly brilliant and began on the right track, he veered away into madness and produced from his own psychoses that depressed and depressing world of chance, that world at once random and mechanistic (a machine gone wildly out of control) in which we all grew up and are only now growing out of.

I searched for the source of Darwin's madness, some moment that 
threw the powerful engine of his mind onto its permanent sidetrack. The clue to that madness came to me in a flash of intuition when I was reading of Darwin's attempt to stimulate movement in the pinnae of his Mimosa Pudica by poising himself before it and playing to it on his bassoon.

As a former (mercifully with a brief career on the instrument) oboist, I knew the truth. The plant never quivered (though it may have suffered great agony), but the action of the double reed of the bassoon vibrated through Darwin's firm embouchure, through his clenched teeth, through the bones of his face and sinuses, through his forehead, the bone thrumming like a taut drumskin, and deeply into his brain. No double reeded instrument player-oboist, English hornist, bassoonist-as all musicians know from painful and personal experience, ever maintains full sanity for more than eight years of play upon his instrument, and Darwin played the bassoon steadily for most of his life.

The key, I asserted in my book, to the darkness and despair of our lives for the last century was that bassoon, for it literally shook the fine mind of Charles Darwin into madness and produced the theory of random selection which continues to this day to deny the place of mind in the movement of nature. Think as you will, says Darwin (or rather, Darwin's bassoon speaking through Darwin), but for all your effort, all your subtle thoughts, you are of no more value or significance than the ringing of a buoy bell on a rising sea, ringing and ringing, random and mad, or a cattail nodding pointlessly in a winter wind, or one of those hideous little dogs with its head bobbing up and down and up and down in the rear window of a battered automobile.

We have been living in the empty, echoing world of a madman's brain for over a century, I said, and the time has come to break out, to impose mind on bare fact, to restore mind and purpose to blank nature by the active force of human will.

So here I am at ITS, a fellow among fellows, all of us fully funded to explore any path we choose, whether out from this hilltop into the vast swirl of cosmic reaches or down through the snarled woods into the enormous bog bubbling and peeping at the foot of the hill.

If Einstein had done nothing else, the awareness that relativity physics has given us of the inescapable participation of the so-called "objective" observer in the event he is observing would have been enough to make him worthy of our sung praises for generations to come. The eye 
and the mind's eye of the human observer and thinker are themselves as much a part of the scene observed as that scene itself. I think of James Thurber peering into a microscope and taking notes on his own eye peering back and realize that he is at that moment the type of us all, all scientists and thinkers, all human beings not wholly caught up in Darwin's thoughtless machine.

We see and our seeing changes what we see. That is the most exciting fact of our existence, for it reveals to us the method whereby we may restore mind to matter and fulfill what must surely be the purpose of our existence. Seeing, thinking, the mysterious power of ESP, the wonders of intercellular communication. We can think cancer into our bones as thoroughly as we can think health into the plant we are watering. The faith healer pounding health into the head of a cripple is the next extension of Thurber's eye: we see ourselves, we see ourselves in the world, we impose ourselves upon the world, we change the world to ourselves, we become the world.

Tomorrow I begin my experiments in earnest.

Today by dint of my careful study of him, eye to eyes, caused a spider to back away from a moth caught in his web. A small, delicate six-eyed spider, an orb weaver; a pale, dull moth, scarcely worth the saving. But, alive-quick! I have, of course, no proper control of the sort necessary to allow me to state my success as scientifically verified fact. But, at this stage, I don't need that; I need merely to convince myself, and I am convinced. I have cancelled the first deadly event in my life as a naturalist; I have made right the original sin of my life as an active participant in the mindless natural world.

That needs, I suppose, some explanation. Somewhere I have stashed away my first naturalist's journal with my original account of the event. But can I find it?

This is the gist: I was about twelve, pimply I suppose, alert, intense, eager to discover everything. For some reason, I had suddenly discovered the existence of variegated nature, a world full of interesting things to observe and note down. It was a major discovery, for it turned daily existence into something as complex and exciting as a baseball game. I had been scoring games I heard on the radio, a complex and cryptic nexus of little lines, diamonds, K's, HR's, BB's and E's, carefully saving the sheets and clipping them into a three-ring binder, sure in the innocence and ignorance of youth that I would be consulting them time 
and again for a lifetime, an eternity to come. And now I had suddenly discovered that I could chart the entire natural world in the same manner, making of each day's observation an elaborate and exciting girandole of birds and insects and mammals and stones and trees and plants, lists and descriptions, a universe in a notebook.

I made the discovery simply because my uncle, a quiet and bearded bachelor, had pointed out to me in a tree in front of our house a female cardinal, a cat bird and a brown thrasher. Before that moment I had been aware of the concept bird and the existence of the particulars, robin (harbinger of spring) and chickadee. But I simply had never noticed the cast of hundreds of differing birds who filled the air, trees, bushes and grass around me every day. I was stunned, overwhelmed.

My uncle promised me a Peterson field guide on his next visit, and I made my first naturalist's notebook that night. I could hardly wait for the dawn to come and woke up instantly with the unnatural vigor and enthusiasm of a Christmas morning. I rushed through breakfast, took my notebook and pen in hand (a practice which I follow to this day), and strode out to greet the wonders of the living world head on.

I paused by the back door and noticed out of the corner of my eye something moving on the windowsill beside me, a slim, almost transparent insect, its clear wings trembling and stretching open in the first warmth of the new day. I tugged a folding lawn chair over by the window and settled myself down on the stiff canvas to watch this tiny bit of life wake up in the early sunlight. I opened my notebook on my knees, uncapped my speckled brown Esterbrook school pen, and looked carefully and closely at the insect.

It stepped very slowly and carefully, once, twice, and then with no apparent transition, it fell over on its side, stiff, dry and dead. I almost threw up. Dead. I had settled down to watch it live, and all it had done was die. I wanted to smash it, to flatten it into the flaking white paint with one quick blow of my fist, to smash it out of nature, out of my consciousness, out of existence. But instead I picked it up by one frail, stiff wing and then replaced it carefully where it had fallen over.

It was a mayfly, I learned later. An insect whose major activity, it would seem, is to die. Birth and death almost in a single breath. This was the gift that nature gave me on my first day as a naturalist. Thanks a lot.

No wonder that I fell prey so easily to the Darwinian world of mad chance. No wonder that I fled from nature to philosophy even while 
I peered back from the ivory tower at that procreating, dying madhouse of nature that surrounded it.

But did nature supply me with that disillusioning surprise by chance? I rejected then and reject now the idea that it was some malignant fate or supernatural overlord who set me up and knocked me down. It was chance and chance alone. But was that chance of my own making, a chance closer to Jung and Pauli's synchronicity than to Darwin's randomness? Did some darkness within myself, some youthful cynicism I was not even aware of, flow out of me and into the world of chance, shaping it to my own dark desires? Did my peering eye stagger that small insect and literally stop it in its tracks? Did I, as Strindberg and Powys thought they did, have the power to destroy with a glance, a wave of living thought? Do we all share that blind and deadly power?

I have come to think that we do, that our very cells are in humming communion with the natural world, the universe, the cosmos. Foucault's pendulum, turning not with the movement of the planet, but with the actual rhythm of the cosmos, comes as no surprise to me. I feel and have felt it for some time in the marrow of my bones. We are of life; we give it mind and meaning, directly, purely, truly.

Thus, my excitement today when the six-eyed spider moving down his orbed web toward the struggling moth withdrew, not because he saw me (for he had seen me before, had seen me watching him long before the moth touched the web) but because I willed it so. He backed away, paused at the web's periphery, watched me free the moth with my fingertips (careful not to damage the web too seriously), watched the stunned moth waver on a nearby leaf and then gather courage and fly away. Watched and understood. Because I willed it so. I willed his behavior, and I willed his understanding of it. He is the Einstein of spiders now, possessed of an awareness so far beyond that of any other of his tribe (save perhaps that ancient ancestor of his who wove his web at Robert Bruce's unknowing bequest) that he might as well be a different creature altogether.

I did this thing. Today. Mayfly, you are avenged!!

Watched a mantis mating today, actually saw it. Just this quick note. Tried to stop it. The drive to sex and death was too powerful, or perhaps I was too revulsed by the whole thing, the pulsing male, I willed him to leave the female, to stop, perhaps I should have tried tuning my will into hers, to make her stop, he was totally a puppet to his heaving loins, 
scarcely a real thing at all beyond the fact of orgasmic pressure itself, I could not reach him, maybe I could have reached her, but she sickened me, I was afraid of her, her triangular head, those enormous eyes like black buttons, chewing away at his head, eating him, chewing and eating him, devouring him as he pumped his seed into her, and she was watching me with those horrible black eyes while she calmly and steadily chewed off his head.

I failed. I willed him away and I failed. I threw up, right there, the vomit steaming on the ground by them. And I stomped them both into mud, screaming, cursing at them at the top of my lungs, the bottom of my foot wrenching into a terrible cramp, coiling away from them within my boot as I stomped and stomped.

I still feel sick. My foot aches. I feel blank and awful and empty. I can't go on.

I should go back down to the bog today. The principle of the thrown rider remounting the horse. Try the frogs. Maybe the insects were too simple, too deeply mindless to be reached until I have learned how to focus my will more fully.

But that won't explain it. I have urged plants into full and blooming health. I reached the spider so infinitely smaller than a mantis; I reached him (her?). Him, I suspect.

It must have been the act and fact of sex itself. It was like Cortapiedras. The sex drive is so explosively powerful that you cannot overcome it, only channel it. Perhaps sublimation is more central than anyone has supposed, or at least the only way to manage the unreleased power of sex.

I must find Cortapiedras and this time try to focus myself on him, not to overcome the fury of his sexual tensions but to channel them, to aim them at his geological interests.

Then perhaps I shall have laid the horror of those mantis lovers away for good.

I found Juan Cortapiedras in the snack bar finally, after winding through the blue labyrinth of the halls in the laboratory building (the blue halls are to calm you between yellow study and green lab). He was with Miller, the balding energetic cancer man, and Gilbert Austin, the English psychologist and philosopher, who was sipping something from a large beer stein and discussing the details of some gruesome British 
murder or the other with apparent relish. I was rather shy of both men, awed by their fame, put off by their casual manner (as though they didn't know their own greatness or refused to accept the consequences of it).

I finally caught Cortapiedras' eye and beckoned him over to my small table as the three were rising to leave. He waved a quick, friendly goodbye to Miller and Austin who wandered on away, and then came over to me.

"Chuck, Chuck," he said, before I could say a word, his hands continuing to wave, this time at me, excitedly, "Have you heard? Yes, you have. No?"

"What, Juan, what?"

"The new associate, the one Dolgrum has taken such a long time picking up, yes, she is a woman, is going to be a woman, a young woman, yes." His eyes were flashing (quite literally), and I was as overwhelmed by my good luck. You could feel the sexual force radiating from him, washing over you like an eighth wave at the beach, hot, wet, salty, overwhelming.

He continued to talk excitedly, his hands shaping the classic woman shape in the air, assuring me that she would be young, beautiful, loose, horny, long hair, eyes, lips, boobs "like nothing you ever seen, yes," legs.

I let him talk on, looking steadily at his eyes (like looking into an old woodstove through the tiny isinglass window in the door), tuning my mind in to the force of his lust (mounting word by word).

"Who is she? What's her name?" I asked, to keep him talking, to keep the fire burning.

"Chuck," he shouted, "Chuck, who knows, who cares?"

He then began to repeat his imaginative description of who and what she must be, and as he spoke, I suddenly lashed a thought, a command, full force at him, my every conscious cell (all of my cells, I believe) sending the message to his every cell. Not cancelling his lust but redirecting it to geology, assenting with his passion and thinking geology, lusting for geology all the time.

He faltered, he stammered, he stopped.

"But Chuck," he said, the passion still in his face, in his voice, "But Chuck, I got to go. I just remembered. I got to get to a geode," he nudged me across the table as he got up to leave, "put the chisel in, crack her open, yes, get into a geode, yes, yes. See you, Chuck, got a heavy date with a geode, hot damn." 
And that was it. I did it! I did it!

He practically ran out the snack bar so eager was he to assault a geode. I was beside myself with joy. I am sure now, totally sure that I am right. I can win. I must plan a laboratory experiment to prove my theory for a doubting scientific world. I can do it. I gave myself a Fifth Avenue!

One problem: It is almost like some sort of electrical backlash. How can I control it. All I can think about is the new woman. I see her everywhere. Or I see Juan's image of her, the legs, the breasts, the face, the long black hair. The sexual tension is stronger than any I have felt since I was a teenager, I want her so bad.

They are all reacting to the news that she is coming. Cortapiedras is polishing himself up; everyone is straightening up their studies, tidying their bedrooms. But I want her, I want her with all the fury of Cortapiedras' lust. The power of it is literally shaking me all over, but I refuse the only release available to me. I will not stoop to that again.

I'll work on my experiment. I shall. I will.

Must determine the exact nature of my experiment. I know now that I can influence the direction of thought of another man, but lack the apparatus here to produce a controlled experiment which would convince anyone, especially with the air cluttered with ESP traditions, Zener cards, thrown dice, stars and bars, circles and pluses. Must remember von Frisch's theorem: "If we use excessively elaborate apparatus to examine simple natural phenomena Nature herself may escape us." Where exactly does he say that? Must look up The Dancing Bees in the library here. Maybe ask Collembola about it. In fact he may have the stuff in the lab that I need. Insects might well be the place to start formally just as they have been all along in my own private studies.

Try as I may, I cannot get her out of my mind. My frequency of urination has increased; I find myself swallowing air and belching it back nervously; I start up from sleep at the slightest sound. How can Cortapiedras stand it if this is the way he is all the time?

She is due here tomorrow. In the morning.

Copies of an article by her were circulated to us all at dinner. From Ms. magazine. Her name is Sara Band. No picture. No author's biographical note. Many fellows seemed to be reading it over their meals. I could hear a good deal of talk, some very vigorous, a lot of laughter. 
I avoided it all, pled a migraine, rushed to my room. The title is interesting, if a bit puzzling: "Psyche-Myth and Moth: The Bag Worm as a Type of Oppressed Sisterhood." I started to read it but could not keep my eyes or mind on the page. Cannot think of my work either. Must try to go to bed and get to sleep early. Maybe I will find relief in my sleep.

Sara.

Slept through and missed her arrival.

Nightmares of the mantis mating, my foot covered with mantises, then my head. Would wake up sweating and writhing. Drift back to sleep. Repeat. Repeat.

Must go by Dolgrum's office. Ask for an introduction. Make apologies.

Still haunted by the black eyes of the mantis. Almost feel them watching me now, black and huge and hungry.

So much has happened today. Some of it productive, I suppose. At least I have the von Frisch book and a lead on the experiment I must construct.

Before I forget it: the von Frisch quotation which I copied down years ago is, alas, on p. vii of The Dancing Bees. Collembola's copy is the English edition (British?)-Methuen, London, 1954. A shame. Now, if I note the page properly, everyone will assume I only read the preface. What to do?

But, I must put down the events of the day, my most social day, my meeting with Sara Band. My feelings are terribly mixed at the moment (anger, shame, regret, some lingering lust), but my memory is sharp.

I arose late, dressed casually in Levi's, my blue Lacoste knit shirt, blue seersucker jacket, sneakers, my usual working garb in summer, and went across from the dorm building to the administrative offices. It was nearly noon, and the brown gravel (pebbles?) of the walkways had already been raked smooth by the groundskeepers. Again ITS' desire to maintain the air of calm rationality even on the paths. I had seldom visited the ad building, and by the time I had located Dolgrum's office, he had gone to lunch. I dared not ask if Ms. Band were with him.

I went to lunch myself along another pebbled path, my eyes scanning the gravel for hints, his footprints, hers. But the rakes had been at work here, too. I began to hate their ant-like efficiency. I had to stop in the 
Men's Room before going into the dining hall (the usual malady), and then all my tension remained unresolved when I discovered the room to be nearly empty and especially empty of Sara Band.

I did see Juan Cortapiedras who waved me over to his table. I made my way to him, balancing the tray with some lunch or the other on it which I had failed to notice really.

"Ah, Chuck," he shouted, "You have seen her, yes?"

"No," I said and shook my head and started to explain, but he pressed on, his voice running over itself, tripping like a clumsy hound puppy.

"Oh, you will be so pleased, yes, she is exactly as I described her, exactly. What a piece! Yes, exactly. Oh, you will like her, yes."

Exactly. I belched nervously and tried to concentrate on getting my lunch chewed and swallowed, over with.

"But Chuck," Juan continued, his voice dropping a little, almost conspiratorial, "I hate to run, but I got work to do, you know, new stones, yes, but I promise you," this time with a wink and nudge, his elbow banging into my shoulder, "I tell you one thing, yes, I promise I'm going to get into that hot pants piece before this day is over, yes," he began to laugh as he spoke, "I'm going to flutter over to her house and do my thing, watch her stick her tail out the door and bang bang, eh, Chuck? She stick it out and bang bang, yes?"

I had no idea what he was talking about beyond the crude essentials, but I nodded as though I were in on the joke. He walked away, stowing his tray, piled high with dishes and forks and knives and crumpled napkins, in one of the large carts left about the room for that purpose (no waiters at ITS, only busboys) and winked at me as he passed through the main door.

Why would Sara Band make Juan think she would "stick her tail out the door?" It made no sense, and I felt none of his usual lust, that overpowering, shuddering force. Just his gaiety, his laughter.

I finished lunch without noticing and made my worried way to Hector Collembola's lab. Collembola, a tiny little man, taut, seemingly ready to spring at any second, is a friendly enough man, not boisterous and open like Cortapiedras, quieter, more abstracted, but filled with a kinetic energy which I could feel as strongly as Juan's sexual cravings. Just being near him inspires me to make a larger effort, to leap higher.

He found me the copy of von Frisch I asked for, told me to take it along with me. Then, in response to my asking what insects he might have that I could use in an experiment in intercellular communication, 
he forced a copy of Henri Fabre's The Life of the Caterpillar on me, saying that the only things he had in sufficient quantity were a colony of pine processionaries. I knew of Fabre's famous experiment with them, but Collembola insisted that I could find something new and interesting to do with them if I read through Fabre thoroughly. And, he added, I was welcome to all the little caterpillars I could use.

I started to ask him about Sara Band, but he was clearly impatient to get back to his worms and bugs, so I left, thanking him, promising to return the books tomorrow.

And then, totally by surprise, I met Sara Band. In the hall. Outside Collembola's lab door. With Dolgrum.

She was dressed in a green pants suit that matched her eyes, a cold green, edgy and deep. I got the feeling that those clear eyes, if they ever cried, would not cry warm tears, but clear, cold, green tears without a trace of salt.

You see, she is nothing like my dream (Juan's dream), nothing at all. She is young, in her twenties I'd say, medium height, could tell nothing about her body in that suit except that she seems slim, she has a bosom though nothing like the vast overwhelming one of Juan's imagining, her face is pretty enough, freckled, she wears large glasses with thin rims that circle her eyes and much of her face like a delicate picture frame. Her skin is fair, her shingled hair is deep red. When I shook her hand, it seemed as cold to me as her eyes, icy, frosted. But enough of Juan's sexual fury remained in me that I stood there desiring her (no doubt obviously), staring into those green eyes while Dolgrum grumbled through an introduction.

"I'm sorry about your headache," she said.

"Headache?" I couldn't make it out.

"Professor Cortapiedras, your friend," she added with what seemed some irony, "told me all about it this morning."

"Oh, my headache," I said, finally remembering my clumsy ruse of the evening before. "Yes, of course, my headache." I think I may have rapped on my forehead with my knuckles.

She smiled a cool little smile (a hint of small white teeth, thin lips, sharp teeth) and said, "Yes, your headache. Probably the result of your years on the oboe."

I was baffled. How did she know I played the oboe? I must have looked the perfect oaf, standing there, staring at her in a mixture of desire and confusion, my hands groping the air as if they could grasp either the fact of her or the mystery of her remark. 
Then, of course, I understood. My book! She had read my book! I was stunned. I was overjoyed. The image of her, this cool pale creature in green with her short red hair, filled me as totally as Juan's mad pneumatic raven haired beauty had. I trembled with joy. I stifled a belch. Completely unconsciously, as I had done thousands of times before at Albert, I dipped my hand into my pocket and came up with a Bit-O. Honey which I handed to her.

She took it, but she looked at it with an odd expression, as though I had handed her an animal dropping or, worse, one of my own. I stammered. I started to try to explain, but Dolgrum broke in (something about things to be done, some pointed remark or another) and led her away. She nodded at me, once, very coldly. She dangled the candy from two fingertips as they walked away down the long corridor. I believe I saw her show it to Dolgrum. I think I heard them share a laugh. I know I saw her toss it into a wastebasket just before they stepped into the elevator at the end of the hall and disappeared from my view.

I stood there, a blue shadow in the blue hallway, watching the empty silence for a long time. Then I came back here. To try to sort things out. To try to work. To try to live.

Fuck Albert!!!!

\section{Women.}

The whole problem. I remember walking Alice's dog, a pooch of some sort or the other, shaggy brown and white, small. (Have I mentioned that Alice was the woman I lived with? Should I? Or should I depersonalize it all? Or use false names? Alice = Carroll (Carol?). Or Alice $=$ Elise?)

Get this right.

I was walking a small dog, shaggy little fellow, brown and white, eager nosed, friendly, when we met, a few blocks up the street, two black dachshunds. They ran down their closely clipped lawn like two wiggling sausages (has that been used?) or two torpedoes, straight for the pooch and me. The first, a male, sniffed at my dog who sniffed back; they maneuvered themselves properly head to tail, both tails wagging stiffly and steadily. No problems. But the other dachshund suddenly moved forward; my dog turned to meet the approach. The second dachshund, with no provocation, just that same wet nose, that same wagging tail, snarled, snapped its teeth, darted forward and back, began to bark angrily. The first dachshund then joined in, abrogating whatever 
treaty he had worked out with my small pooch. The second dachshund was, of course, female, a bitch.

Should be able to add a good deal to this. Not the overworked Black Widow tale. The mantis is too close to me, too deep, to use, to waste in anything other than the book. Must look around for other examples.

Why am I so angry? Tried to read Band's article. Again could not focus. Settled down with von Frisch. Found my quotation quickly. Wrote my notes in here. Then settled down in an armchair in the philosophy library (where no one seems ever to venture) by a narrow window facing the woods and the bog. And read her piece. It shouldn't bother me. Is this just frustration from the whole complex of emotions which were betrayed by my meeting with her? Or am I annoyed that the author (I am tempted in my anger to say authoress) of this garbage should be invited here to ITS to work with men like Juan Cortapiedras, Gilbert Austin, Hector Collembola, myself?!?

I stared out of the window toward the bog but saw nothing. I have been planning a reply, an article, a popular piece for a popular magazine (should I try Playboy or Penthouse?) exploding her thinking and her method. Turning her own guns on her. The bitch!

I must get back to my work. I'll try to read Fabre and think about pine processionaries.

Real advances. Real advances.

The whole thing has come together this evening with extraordinary clarity. I read Fabre's chapter on pine processionaries. To keep my mind working away from Sara Band and her abominable piece, I read the rest of Fabre, a remarkable book, the man a great scientist not so much for his observations but rather for his allowing his imagination to flow into those observations. He does not merely look at pine processionaries, he feels them. But, as I read on, I found a chapter on psyche moths, and (!!) I found the details of Band's piece practically intact. Without a word of acknowledgement, she has lifted Fabre's study of psyche moths and applied it to her own cheap purposes. I almost danced around the room. I felt freed of the need to refute her. She was a common thief. Why bother with an article in response, when a simple letter to the editor will do? If they accept letters from men.

But, in my elation, my excitement, my victory, I suddenly discovered my experiment with pine processionaries. It came to me in a sudden brilliant flash. I'll borrow the necessary caterpillars from Collembola tomorrow. It is so simple and so clear. The results will be irrefutable. 
Tonight I will sleep deeply and freely, the succubus of Cortapiedras' imagining finally and successfully laid at last.

Woke up at 3 a.m., can't go back to sleep, too groggy to work. Memories of dreams, indistinct, disturbing, chilling. Was wet through my pajamas but cold. Had to walk around and around the room, slapping at myself, thighs and shoulders. Was she in the dreams, those cold eyes, cold hands? Were they sexual? I only remember struggle, furious struggle, an overpowering sense of being swallowed by something, smothering, drowning. Yes, and a distinct presence. Of Sara Band? I almost remember now.

Must do something. My nerves are fraying in the night. Will make notes on her article. Perhaps I can find a way to work them into the book, a rational solution to the dilemma she professes to describe.

"Psyche-Myth and Moth: The Bag Worm as a Type of Oppressed Sisterhood."

Part One: a rehash of the Cupid-Psyche myth. Psyche as abused woman, how the gods conspire to hurt her because she has pride in herself and her beauty, how Cupid with typical male territorial and sexual instincts steals her away and forces her to make love to him in darkness, never allowing her to see him, his penis according to him enough reward for a life of loneliness and the fear of being turned over to a serpentine monster (as though he were anything other to her himself really) if she displeases him. This use-abuse of Psyche by Cupid is, according to Band, the heart of the myth, the terrible truth about woman's place in a male world. The rest is male cover-up, the business about Psyche redeeming herself by labors (the kitchen as path to salvation myth) and her final reward, immortality through the birth of a child called Pleasure (the myth doesn't mention the real labors of childbirth which make the seed sorting and fleece gathering look like a picnic).

Her conclusion: that the Psyche myth unconsciously reveals a great truth about human behavior. The female, Psyche, is kept a sexual prisoner and made a virtual slave by male duplicity, and the only escape available to her, according to the male lie, is to accept the male penis in her as a suitable reward and bear a child as her only pleasure.

Part Two: a rehash of Fabre's chapter on psyche moths (bag worms). How the larvae, male and female, begin constructing houses, the familiar leafy bags that dot dying evergreens every summer, immediately 
after birth. How the caterpillars live in these bags, carrying them on their backs wherever they wander. But then they become moths. The male (and she quotes directly from Fabre without admitting it) "wears a costume of deepest black, all except the edges of the wings, which, having no scales, remain diaphanous. His antennae, likewise black, are wide and graceful plumes." The female moth, however, is horribly ugly, wingless, a tiny head, vestigial eyes, tiny weak legs, her body pale yellow, the bulk of her body a bag swollen with eggs. This poor female, looking like a maggot, stays forever in her house; she does not break forth like the free, handsome male and fly in the warm night air.

Band really gets worked up here, drawing myth and moth together in her spidery web. The male, like Cupid, comes to the female Psyche in the dark and screws her. They do not even see each other. The female lowers her tail out of her bag home, and the male puts it to her. (Suddenly I understand Cortapiedras' jokes about Band's "sticking her tail out the door." But where does he stand on her? Did he mean it?)

Anyway, the sex act over, the male flies, according to Band, happily away, to live out his life in the free air, a typical male chauvinist. The female, again like Psyche, finds her pleasure in her young. She never leaves her home for her entire life. She lays her eggs and ends what is left of her life in the doorway of her home, protecting the eggs and then leaving her poor broken body for their future use.

Part Three: Band's conclusion. That both Psyche the myth and the female bag worm (for even the moth is more worm than moth) are types of oppressed sisterhood. That the woman who submits to a man's gropings and pumpings, allowing herself to be turned into household drudge with no reward but his penisolate gifts, is as foolish and benighted as Psyche in the myth and as cruelly imprisoned and put upon as the female Psyche moth. The married and oppressed woman is in fact nothing more than a bag worm (she lingers over the appropriateness of the name and the uses of "bag" in male slang).

The only answer, she says, is for the female to throw off the shackles of male myth and nature alike. Refuse to accept the Psyche role imposed by male mythic romantic notions. And (this is the radical part of her piece) refuse to accept the bondage of nature. Refuse the house. Refuse the role of egg layer and child bearer. Whether by knife or pill, circumvent the power of the ovaries. By force of will, grow wings, soar away into the starry night, fly away to the heavens of freedom, free of children, free of the oppression of men, free of the bondage of nature 
itself. And by her actions make Mother Nature herself over into Ms. Nature!!!

Need I say more? I think now I can finally get some sleep.

Spent most of the day setting up my experiment in a corner of the biology lab, a huge room swarming with glass tubing and green plants, insects and animals-even the special air conditioning can't remove the strong traces of jungle atmosphere, musk and droppings, the steamy breath of plants, the buzz and chir of the bugs and clicking beetles. I am still astonished by Collembola, the absolute ordinariness of his appearance and the extraordinary vitality of his presence, the spring of his walk, the vigor of his expression. He gave me a procession of twelve caterpillars, a supply of pine branches with which to feed them, helped me fashion out of quick drying plaster a cylinder with fluting which roughly approximates the one used in Fabre's famous experiment.

Should I explain Fabre's experiment, or is it too familiar? Maybe very briefly, how the processionaries follow a thin silken thread laid down by their leader (a random leader, simply the first caterpillar in line) out from and then back to their nest, each caterpillar leaving a fine silken thread of his own, all of them forming a slim shining pale white trail along the way. Fabre set a group of them going round a large palm vase (or, rather, they climbed the vase, and he tricked them into following themselves around and around it). The caterpillars all faithfully followed their leader, each one of them both leader and follower, all of them going nowhere, around and around. For seven days they walked stupidly around the vase, eating nothing, always walking, going nowhere. Fabre was struck by "the lack of any gleam of intelligence in their benighted minds." In short, they are the perfect type of mindless Darwinian nature, life going nowhere with steady concentration, living beings bravely following their natural leader round and round that vicious circle when that leader is quite simply not there. Fabre's experiment is a favorite of Darwinians and reductionists who are seeking easy proof of the mindlessness of nature.

The answer is, of course, that they are not leaderless, but that each little caterpillar is himself the leader, able at any moment to launch out on his own, to lead all the others to safety. Each tiny caterpillar has the potential, given him by the very nature that seems to have doomed him to mindlessness, to become transcendent. And if they seem, as Fabre shows, incapable of making this leap on their own, then it is clearly our 
responsibility as the bearers of mind into the world to supply them with the necessary information and stimulus to make that leap from mindlessness and purposelessness to thought and direction, from worm to Überwurm.

Anyway, we made the plaster cylinder and, after some minor difficulties, succeeded in getting the small procession of twelve caterpillars crawling in a wavering line around the cylinder's rim. No tiny trail, after some careful rubbing, remains that could lead them down. Round and around they go. I shall let them continue their pointless journey until tomorrow or the next day (I must remember to ask Collembola how long he thinks I should let them go in order to establish the hopelessness of their plight, the mindlessness of their condition). Then I shall by intercellular communication alone instill in them the mental power to see their situation and to correct it. I shall give mind to the pine processionaries and bring them down to their feeding place (without, of course, any intercession of ordinary physical apparatus, stick, string or tweezer).

I am confident that I shall be able to repeat my success with the spider in this controlled experiment under laboratory conditions. I have no doubts. I am filled with a strong sense of power and purpose.

Saw Sara Band at dinner tonight but resisted speaking to her, mentioning Fabre and article in the same breath, watching her realize the trap into which I have forced her, her rising panic and sinking despair. Instead, I ate alone. She did not appear to notice me either.

The others are like birds stretching out their wings to display their plumage or frogs ballooning their rubbery throats out into airy splendour. Six men at her table, and despite the stern presence of dour Dolgrum, all of them laughing loudly, waving their arms, talking at once, their noise echoing around the room like (again) a chorus of summer frogs, burp, boom and harrumph. Cortapiedras, so clean shaven, so smooth, brushed and combed, so polished that the light seemed to dance off him and dazzle the air.

And her face, always between someone's arm and someone else's shoulder, triangular, her red hair like some sort of dark flame, absorbing light, surrendering no warmth, her eyes hidden and expressionless behind large round dark glasses. She nodded at their jokes, never laughed.

I paid her no mind. Have come back to my room to read, relax, retire early. Tomorrow may bring real excitement in the lab. 
Of course, no sleep. Only nightmares. Only book to read, since I had read Fabre, was von Frisch. So I read about bees, then put the book aside and drifted into an awkward and uneasy sleep, my hands clenched on my chest.

And dreamed of bees. The room full of bees. Buzzing and humming, dancing in a huge circle, wagging their wings and tails, telling me something, something I could not decipher. What could bees be telling me?

Then from the whir and confusion a hideous scene with workers driving the drones away from the queen. The drones battered and bleeding, almost wingless, their wings shredded down to the stumps. The queen an enormous bee, her eyes huge and black, her body, furry body, glowing deep orange, dark red. The drones buzzed horribly as the workers swept them away. Then the queen turned those horrible eyes toward me, to me, turned to me, her head huge and enormous, I could not run, felt numb, heavy weights pressing me down, the workers holding me, her huge head, her mouth, she began to chew at my face, my ears, she began to eat me alive!

I woke up, sweaty, both arms asleep on my chest from elbow to hand. I tried to fling myself up but could not rise, could not throw off their weight in the darkness. I struggled but always sank back, drowning in myself, my own dead weight. Finally heaved myself over, threw my legs out of the bed, knees hitting the floor with painful thumps, my arms dangling like lead sinkers by my sides.

Finally restored circulation, turned on light. Decided to write all this down, clear my mind of bees and dreams before I dare try to return to sleep. But I must sleep to gain a clear head, purity of mind, for tomorrow.

Slept late. Of course. Am noting this in an attempt to keep the shape and detail of this eventful and major day absolutely clear and fresh in my memory for the book. For posterity? At this yawning and stretching moment I can only hope.

The rest of my sleep was, for the record, dreamless. I seem calm and alert. I shall go to lunch and then to the lab. Will most likely see Collembola at lunch, ask his advice and assistance. And now to my toothbrush.

Can I write this down?

Has ever man been so sorely tried? 
I think I can write it now. The sun is down. I spent the evening in the woods, far from the walls of my study which I kicked and pounded until their yellow was scuffed and scarred and my hands red and aching, far from the society of men, far from that one woman, that bitch, that whore, far from the lab, from the green slaughter of innocents.

And now I am in my room. I am calm. I can think. I can write.

I went to lunch. Collembola was not there. I did find Juan Cortapiedras who said that Collembola had been there briefly, had been quite upset about something, was seeking out Dolgrum to complain about something, something to do with Sara Band. And then, of course, her name mentioned, he swerved away from the subject and onto her. Had I made it with her yet? Had anyone? Promises that he would himself do so soon, that he would tell me all immediately, that I would in fact be the first to know. Good stuff, yes, good stuff. On and on. His eyes shining like jet black gem stones, a fire gleaming somewhere in their stoney depths. I was almost nauseous with his intensity.

I excused myself and walked the gravelled paths to the lab. I swung the green metal door in and entered the large room. Aware only of a strange and heavy silence, I at first thought I was alone. Then I heard the sounds of someone moving briskly about, someone humming, no tune, just a humming, steady and monotonous like that of a small child at vague play or the pointless droning of an insect.

"Hector?" I called out, sure that it must be Collembola puttering over one of his experimental arrangements.

But it wasn't he. It was her. Sara Band, her hair tied up in a bright (bilious) green bandana, in a green smock and pants, sweeping vigorously with a broom, a dust pan dangling at her side, hooked to her belt like a slide rule or a pistol.

"Oh, Doctor Cotswaldo," she said, apparently surprised, with an edge to her voice, a slight one, not sharp enough yet to cut. That was to come later.

"Oh, Doctor Cotswaldo, Doctor Collembola isn't here just now. Just me. Just tidying up."

I tried to say something, failed, stood there, my hands in my pockets, my feet probably fidgeting, probably scuffing the floor like some cinematic adolescent's, the urge to reveal my knowledge of her duplicity growing stronger second by second, my awkwardness in her presence 
(some residue, no doubt, of Juan's desire still burning in my bloodstream) keeping me there, keeping me silent.

She went right on.

"He was here though, though how he could stand it, I can't imagine. Actually I can-enjoying with typical male pleasure the mess he was making of a perfectly orderly situation.'

Why she was so voluble, when before she had scarcely said a syllable, was beyond me. Nor did I understand, then, what she was talking about.

"So I cleaned up. It made him furious. Seeing a mere woman on his turf, invading his precious territory." She laughed, and the cold I had felt before in her presence knifed through me again. A clear crystalline little laugh.

I nodded, nodded only.

"Aren't you proud of me?" she went on. "Don't I win at least an M\&M?"

I almost staggered. I may have leaned back into the door. But she turned and was gone before I could utter a sound, even swallow. I looked after her, green and small and (I admit it) shapely as, carrying her broom and pan dangling, she walked across the lab and through the other door to the service rooms beyond. Only then, the room finally mine alone, did I realize what was wrong with it before, why it had seemed so particularly empty. The familiar and busy chir and whir of the insects, Collembola's various experimental insects, was silent. The room was quiet as a tomb or killing jar. Not a shrill nor chitter.

I moved across the room, almost numb with a rising fear, to my plaster column. And it was, as I had feared, clean, smooth, dusted and empty of life. Not a single tiny caterpillar marred its blank surface. Even the silken record of that small procession was gone. No pine boughs lay at its foot. Everything sterile and clean.

I stifled a roar of rage and ran across the tidy lab to Collembola's large glass terrarium, the one in which his pine processionaries had been making their explorations the day before.

And it was empty. Clean. Polished. Empty.

She had killed them all. I could feel it in the very air, vibrating with soundless intensity. She had killed them all!

I heard a sound behind me and whirled around. Now minus broom and pan, she was standing there, smiling at me. Again I was struck dumb, speechless and doubtless slack jawed.

"This place was literally full of worms," she said, calmly and with 
no little pride, "worms and bugs and litter. But no more. How anyone could have worked here is beyond me. I surely couldn't have, but now," and she paused and smiled, showing her small, even, pale teeth, "but now, I'm sure I can."

I haven't written in here for three days. For three days I have walked alone in the woods, eaten alone at meals, kept to my room from sunset on. For three days I have been so nervous and uneven in mind and spirit that I have not cared what I saw or did, scarcely saw what I was looking at or even looked at anything worth seeing. I have avoided the lab. She is, I am sure, there all of the time. Collembola has left ITS, left angrily, threatening all sorts of things. I don't know what Dolgrum said or didn't say. But the lab is hers now, and, for all I care, hers alone for the rest of the summer. I certainly shall stay as far away as I can.

I have been walking in the woods again. That and lurking in Austin's office, near mine but far enough away to avoid unpleasant confrontations should anyone (she) come looking for me. Austin has been away for the last week and won't return for another two.

I was going to describe things I have found and seen in the woods and by the bog, but I am drawn to describe that office briefly. It is a yellow study like mine. I think I call it an office (which I have been doing quite unconsciously) because he has moved into it so thoroughly, bookshelves along the walls, framed degrees, a picture framed and carefully hung by the window. The bulk of psychologists I find annoying and objectionable, whether luring you onto their couches of forbidden memory and pain or giving you vacuous grins and telling you how okay they are and you are. But Austin shows great evidence of mind, of curiosity, of thought.

I examine his books, the usual shelves of clinical studies, but others as well: Bergmann's Meaning and Existence, Dewey's Existence and Nature, even (!!) McTaggart's The Nature of Existence. The range pleases me: Wilson's The Occult by Becker's On Justifying Moral Judgments, Heisenberg's Physics and Philosophy alongside Velikovsky's Earth in Upheaval. His own books-Homage to Edmund Husserl, Life, Being and Language, Miscellanies. Lying on a table by the window (overlooking the woods, the bog) a copy of Darwin's Bassoon, the back bent as though he read it, some annotations in pencil which I lack the courage to examine.

The picture on the wall: six stern psychoanalysts peering at the 
camera as though attempting to peer into its inner recesses, Freud with his cane, a cigar in his fingers, seated clutching his hat tightly, looking almost as though he were ready to burst into neurasthenic tears; and on the other side of stern ancient Hall, close-cropped Jung, squinting at the camera, holding his hat delicately and carefully, glasses clipped to his narrow nose. If I should remove the photo from its frame and fold it precisely down the line of Hall's nose, Freud and Jung would meet face to somber face, beard to moustache, eye to eye to eye to eye. I am tempted to do it. What sparks would fly, the paper curling back like the fine gold leaves of an electroscope diverging with the charge of that old antagonism.

I am sitting in that congenial room now, the late afternoon sun warming the small window, gleaming off the table, the jacket of my book, the picture of Freud and Jung dimmed by its pleasant glare. The entire room, yellow walls and warm wood, glows in the sunlight. It warms me in some primal central way despite the sealed window, the whispering air conditioner. I shall turn into myself, into my memories, away from the buildings and frustrations of ITS and into the woods, the bog, the swarming vital natural world.

The path down to the bog winds through the vegetation, the pines and persimmons and maples, the broadleaves and conifers, the sweet patches of honeysuckle and strangling kudzu, the undergrowth of bulging May apples and shiny poison oak and ivy. Horned beetles doze the soil, rummaging for sustenance, steady and hard-shelled. Mole tunnels wrinkle the path, sinking with a surprising softness under your bootsoles. Birds whistle and chuckle in the leaves, invisible, always audible, occasionally startling the eye with a flutter and flurry, a quick winging away, a dart of blue or red or rufous brown. The heat of midday enfolds you even in the shade of the trees. In the clearings the sky lies hazily overhead, a dulled blue as though it were moist with the warm breath of tall trees.

You are alive in this living world, but it tempts you in its steadiness to surrender your mind, the edges of your thought, to its dullness, its enveloping physical malaise. You stir within yourself; you press out into this natural confusion; you focus it like an eye or the lens of an observing instrument.

A young rabbit, pale brown, a white fluff of tail, the eyes large and almost frighteningly open, still as a bush or tree, watching you: a small 
frail creature, the sunlight behind it. The light flows through the thin membrane of its ears; you can see the blood moving in the large blood vessels in those ears, the pulse and rhythm of life even in those delicate bunny ears. And then you see the ticks, three swollen pale-gray blobs, leeched onto those thin ears, drinking out the life as you watch it. You start to think yourself into the rabbit, into that small round head, to urge it to you, to let you pick those repulsive suckers off and out. But it suddenly darts away, stung by your mind or startled by some movement of which you are unaware. The tall grasses tremble with its passing and are still. The sun sinks in the late afternoon sky; the tree leaves blink and stammer in your watering eyes.

You turn away. A dead bird, more a mash of feather and down than a real corpse, sinks slowly back to earth by your foot. The air is caught by the soil as the sun sinks down and down. A spider web ensnares your face. You brush it away with a startling violence. You shudder and are suddenly afraid. Not of spiders or of ticks, not of the sunning copperhead stretched like a curved bronze knife by the path, not of dead birds or dying rabbits. But afraid of the enormity of the task you have set yourself, which you demand of your fellow man. To give mind and meaning to this, to this mass of snarled being, of life and death woven like a tangle of vines, the sweet white blossoms almost lost in the choking leaves. You are afraid, and you run for home, for life.

It has grown dark in the study, and that dark has worked itself into my prose. I feel weary and weak. This friendly room seems now alien and dangerous. I must go back to my room, to my bed, to my dreams, such as they are.

No dreams. None that I remember.

I am walking more and more. Good for my lungs. They buoy me up and bear me on. My legs no longer feel the swells and hills. Down to the bog, circling in through the high brush and wet soil, around it, narrowing my compass every day. Stepping occasionally into the water, concealed by the weeds and reeds, and limping back to ITS with a wet boot and sopping sock.

Bag worms, Sara Band's psyche moths. I doubt she's ever seen one. I am collecting a set of empty cases, former homes of male moths now flown away. Aided by Epps' Guide to Familiar American Trees I am categorizing the materials of their construction: one made of the eastern spruce, the shell a brittle gathering of the four-sided needles, sharp and 
hard and somehow nordic, spikey and gothic; another formed of red cedar, the flat faintly sticky brown leaves giving it a soft southern texture, rounded and classical; another, the home of a worm strayed away from conifer to wild cherry, the case an almost pathetic shanty of crudely cut leaves, like a tattered shawl pulled over poor shoulders. She probably wouldn't even know what they are. If I left them on her desk, she would probably squeal and mash their sturdy architecture, or sweep them with a squeamish notebook into the wastebasket.

The bitch.

I am so happy that I don't think of her any more.

A wet dream last night. A reminder that I am still flesh as well as mind. I don't remember the precise terms of the drama. I felt as though I were in some soft cocoon or pressing into one. Flesh and flesh in a silken web, and then I awoke damp and dissatisfied. I must free myself from this necessity, from necessity.

I have it! The source of sweet revenge! I shall destroy her with the best weapon at my command. My own mind. The knowledge I have gained from my experiences with Cortapiedras. The power of sex channelled this time not into good work but into damaging disarray, hers, hers.

The plan: Dolgrum, the director of ITS, despite his apparent delight with Ms. Band, is a stern and puritanical man. He expects nothing but solid work from the fellows here at the institute. He is, I am told, easily shocked by rough language even when no ladies are present (the usual condition at ITS). There has been speculation, but mainly by Juan, about his doings in town on his frequent absences, but they are merely speculations. No proof at all has been offered. He is a cool and aloof man. He is the key to my plan.

I remember a comic fumetti that I read years ago. In it an idle young man, an office worker, while attempting by psychokinesis to cause a banana on the desk before him to peel, unknowingly causes a voluptuous secretary behind him to strip off her clothes. I forget how it worked out, but it and Dolgrum's grim nature gave me all the clues I need.

The next time Ms. Sara Band goes into Dolgrum's office for a conference, which she does from time to time, I shall manage to be in the next room, a small conference room adjoining his office with a pleated plastic folding door between. I shall tune in on her sexual nature, repressed no 
doubt but surely there, and I shall, by mental suggestion, by willing it, direct that energy to the front of her consciousness and by guiding it cause her to peel, to strip off her clothes in the director's very office!

Then, then, I shall be avenged!!!

I have won. And lost. Must every action be holonic? Is the real as absurdly confusing always as it has come to seem this summer?

The time came sooner than I had expected. Band and Dolgrum, alone in his office. And I, secreted in the silent conference room next door. I could hear them talking through the sliding accordion door, but I could see nothing, not even a shadow or pair of silhouettes. I had never before worked my will without the direct medium of sight, of visual connection, but I decided the stakes were high enough to press on, to risk failure and the feeling of foolishness.

I crouched by the door, listened to their innocuous chatter. Some conference. She complimented his tie. He spoke well of her dress, claiming always to have preferred that shade of green to all others.

I focussed myself on her voice. I ceased hearing words, only the voices, the voice itself, hers. I tuned myself to the rhythms of her voice, and I began to think, slowly, carefully, coldly, thoughts the precise temperature and intensity of her own. "Strip off your clothes," no, nothing so crude ... only sexual tension, I felt it in myself, rising, rising, the fury of Cortapiedras' sex, my own, hers (I am sure-hers). And I aimed it into her, into her voice, the shadow I could not see, the cool hard flesh of her body. Sex. Sex. Sex.

And then, knowing the climactic moment in the very sinews of my own crouched flesh, I forced the thought of stripping into her, a rape of will and spirit. Strip. Strip. Throw yourself at him. Tear the buttons of your blouse off in your frenzy. Pull down those tight green pants. The underclothes (how I wished I knew what they actually were, form and texture). Everything off, baring your teeth, cross to him, to Dolgrum, fling yourself on him, naked, naked, naked.

In the fury of this exercise of pure directed will, I fell over backward on the smooth carpeted floor. For a moment, I feared discovery, the shame of being considered an eavesdropper, a cheap voyeur. But then I realized that I had nothing to fear. The only sounds from beyond that plastic barrier were animal sounds, grunts and wet smacks, a growl, the sounds of territorial confrontation, the battering of Rocky Mountain rams, the snorting of sea lions. 
She had done it! She had done it! I could still see nothing, but the sounds made everything clear. She had assaulted him. Sara Band had assaulted Dolgrum. I lay on the red carpeted floor, weak from the effort, my will thoroughly spent, listening to my victory, to Sara Band skewered on the spear of her own sexuality.

But the sounds went on too long. And with too much monotony. Breathings and shufflings. Did something (a foot perhaps) actually touch the pleated door right beside me?

I backed quickly away, scuttled across the red rug like a startled tree crab, crawled up the wall by the exit door, straightened my clothes, smoothed them, and went out.

I won. She stripped herself and threw herself at Dolgrum. I know she did. I know it. But instead of responding as he should have, instead of reprimanding her or leaving the office or even striking her, he responded sexually. That is the only explanation of the quality and duration of the sounds.

Did I accidentally, in the intensity of my concentration, in the absence of eye contact, impose that sexual explosion on Dolgrum as well as Band? Or have I simply misjudged him totally? After all, I scarcely know the man. We have never exchanged confidences nor even spoken seriously to one another. Could he have simply been ripe for the occasion, ready for her to leap bare into his eager lap? I must find out. I am whirling in doubt, sinking in confusion. Cortapiedras will hear all the gossip. I'll venture out to dinner tonight instead of ordering it anonymously delivered to my room. He will know.

No Juan at dinner. When I asked Miller where he was, he only winked a broad stage wink, nodded his head toward the director's table, and said, "You know." Dolgrum was eating alone at his table, no Sara in evidence. I certainly didn't know what Miller was winking and nodding about, nor did I particularly care. I'll stop by Austin's office and borrow a book from his shelves and read myself to early sleep. Then I'll catch Cortapiedras at breakfast. By writing these notes now at table, I have successfully avoided conversation. One advantage of ITS: even the appearance of work is respected by all.

By all but one, I should have said. The bitch.

Saw Juan coming out of Band's study as I was walking to Austin's. Tucking in his red shirt, straightening his yellow trousers, grinning like 
an ape. He may have seen me. I think he winked at me, or then again he could simply have been blinking. I ducked into Austin's.

The whore. She fucks them all. Like some kind of voracious spider. Juan. Dolgrum. Maybe Miller (his winks and nods?). Disrupting decent experiments. Driving a good man like Collembola away. Driving me half out of my mind. I probably had nothing at all to do with her taking off her clothes and throwing herself at Dolgrum. It was probably her own doing entirely. Probably wasn't even the first time. She wears that green jump suit or whatever probably just so her lovers can have easy access to her tail. Just zip open here and insert organ.

I raged. I circled the room in a tightening circle. I could feel the blood beating in my twisted face. My nails dug a path of grooves across each palm. Bitch! Whore! Slut! I cried all those names and more to myself, to the walls, the darkening room. The red sunset was turning its pale walls a deadly orange. I circled in it like a sick fish dying of whirling disease, spinning on my nose in a mad dwindling pirouette of pain. My throat filled with the harsh jelly of hate. I wanted to explode.

And then, suddenly, filling me with a terror that made my nerves race with electrical shock for minutes after, something did explode, with a terrific bang. Glass and bits of paper and wood showered me. The force of the explosion actually knocked several books out of their shelves, and it stopped me dead in my tracks. Electrocuted by the short circuiting of my own tension.

It was the picture of Jung and Freud on the wall by the window. It had exploded. Nothing had been thrown at it. Nothing was behind it except the injured wall. It had itself exploded.

I stood there in the gathering darkness, the orange room fading to a deathly violet, the water of my shocked nerves sinking in my body like draining water in an emptying tank. My knees felt wet and weak. I felt like settling to, even into, the floor.

I could hear footsteps in the hall, excited voices. I knew then in that deep purple room that I had caused that explosion, that my pent up fury and frustration had flashed out of my body, my raging brain, had smashed into that innocent photograph on the wall, had burst it like an egg, like a bomb. I had done it, and I was deeply frightened.

I managed to move across the room, to open the door, to move out into the brightly lit blue hall, to close the door soundlessly behind me. There was no one in sight. The search must have moved on down the corridor, around a corner. I realized that I was bleeding. There was blood 
on both my hands, no doubt on my face (there was). Sliced by the glassy shards of my own failure and frustration, bloody and empty, I slipped away, back to my room where I bathed and treated my ridiculous wounds. Where I am sitting now, absurd, beaten, afraid even to continue my work. What else will she drive me to destroy? What living creature will I explode like a firecracker because of her? Dare I even approach the living world in the state I am in?

I have returned to nature, to the natural world, to the woods and the bog. Chastened, humbled, no longer even sure of the correctness of my desire to give mind to blank matter. Perhaps it is better left alone. Or, at least, no longer sure that I can be trusted to do the job, even to begin it.

Am I in any way different from those slick frogs bulging and humping in the bog, slime covered and squeaking, driven by no ideas but by blind frenzied impulse? I toss a stone into the scummy water at the bog's edge and watch them squeal and plop, scurry away through the green webbed water, and I see myself, skittering across the floor in Dolgrum's conference room, creeping down the empty hall, dodging footsteps and shadows, plunging into my bed, sliding under the covers and diving deep like a frightened child on a windy winter night.

What right have I to impose my mind on mindless nature when I seem unable to master myself, my own glands and juices, the frenetic pulsing of my own ragged nerves?

None. None at all.

But I have returned to nature, to the paths and underbrush of the ITS grounds, not so much to confront the facts of external being as to escape the facts of my own wretched self, unloved and unloving, ashamed to look Juan Cortapiedras or Dolgrum or Miller or anyone in the eye. Especially afraid to see Sara Band in her sleek green zippered suit. I know her secrets, her flaws, her weaknesses, and I cannot face her. So I shall examine the tendrils of climbing vines, the delicately arched paths of meadow voles, the cannibal feasts of my fellow frogs. I shall turn away from man (woman) to the landscape, and in that turmoil perhaps find the calm, the purity of vision, the understanding which I seriously need.

After you walk down the hill away from the silent buildings in the early morning, the leaves of the grass still pale and silvery in the slanting 
sun, the long shadows thin and almost transparent unlike their weary evening counterparts that lean so heavily the opposite direction-after you walk down the hill along the gravelled path and enter the woods, a great silence as though the world were holding its breath, listening, watching for the sudden deadly move in the corner of the eye, the flicker in the ear, the faint scent of death. Still and ominous and terribly, terribly alive.

Tiny warblers plink through this awful silence, the sun filtering through the leaves to touch their golden feathers afire. And then you are by the bog, the steep hill behind you, circling the calm dead water, until finally you reach a nearly flat meadow, the weeds almost waist high now, steady and unmoving.

This morning I met a movement in those weeds, watched it come across the meadow, unwavering, steady, leaving a weedy wake like some land torpedo (have I used this?) aimed directly at me. It broke out of the weeds onto the path, a small (fifteen pounds?) beagle or small hound, a bitch, brown and black and white, the head mainly brown, the flat soft ears, the fairly small eyes dark brown, the nose damp black tinged with the pink of age. An old dog? I was not sure. She was a used dog, that much for sure, the double row of heavy black teats hanging uncomfortably under her belly, the weighty evidence of sex and birth and time.

She trotted right up to me, the brown and white tail wagging tentatively. I stooped to pat her head, to scratch behind her ears, and she looked up at me, those brown eyes filled with such extraordinary sadness that I felt the emotion flow through me, hand and eye, a heavy stoic sadness, surrender, acceptance, a sorrow of the the very nature of things. I actually felt tears filling my own eyes. I understood there for that passing moment what it was to be alive, to be female, to bear the sagging bulk of your surrender to life on you not like a badge of honor but like the chains and weights of some ancient cruel prison.

I started to embrace the small dog, to hug her to me, but she broke away and trotted on down the path, her teats swaying beneath her, her tail wagging like a small white flag. I felt a confusion I have never felt before. I found a tuft of high ground, mashed down the weeds and settled myself to write this, to attempt in the telling to see what I have seen.

That dog needed no infusion of my mind and thoughts, my feelings and values. She had a depth of life in her that filled me, or rather that drew me into her, into her experience, her knowing. Have I been coming at the whole question aslant? Is the answer to enter the natural 
world, to allow its cells to communicate with yours, to enter its flow rather than impose your patterns on it? It is true that my best results have been attained by attuning myself to some powerful natural force (Cortapiedras' lust, Band's perverse desires) and guiding that force, not by imposing thought on static nature.

This could be the breakthrough for which I have been searching, the moment at which all of the pieces of the puzzle slip suddenly together, the crazy chaos of color and shape become a peaceful if too brightly colored alpine scene. I must think this through. Stay here and think this whole thing through.

This day will go down into history. If I can capture it. I know I can't now, but I must get the shape of this afternoon down before sunset. I am afraid to wait until I get back to my room. I must try now.

But it requires a shedding of shame, of human limitation. How to confess something we have been taught from childhood (our own, the very childhood of the race entire) is evil, or at the very least is something to be experienced but never spoken of. At least in daylight or in a lighted room.

I sat in the meadow. I wrote in this notebook. I watched the day grow, the damp leave the grass, the grass stretch erect in the warmth, the buzz and dart of awakening insect life. The dog did not return although I thought of her, attempted to come to grips with what she had given me. And with the problem of how to analyze and ultimately to express what she had shown me. Who would listen? Perhaps an article, carefully phrased, the truth concealed (almost) in the language of the discipline, in the Journal of the Association of Therolinguistics. Then, after weighing the response (if any), a larger piece, one for a different audience, in Mind perhaps. Then the book, one designed to reach an audience as large as Darwin's Bassoon, but one carefully designed to blunt all professional attacks before they can be made.

I note all of this as evidence of my frame of mind. I was in no emotional state, was being totally (even coldly) practical. My imagination, in other words, was functioning completely as an adjunct to my reason; my emotions were behaving solely as a battery, a source of neural energy for the rational process.

The meadow had, for all intents and purposes, disappeared. I was aware of the rising heat, of the light, a vague sense of green grass, blue sky, glare. Then I became aware consciously of something at which I 
had been staring blankly for some time: the green weeds were glittering with flecks of gold, scattered over the stalks and mottled leaves, moving little but catching the light, a meadow of tattered leaves and fool's gold.

Once aware of what I was seeing, I tucked notebook and pen into my small pack and waded into the thick grasses, prospecting for gold. And what I found were clumps of Popillia japonica, Japanese beetles, on almost every leaf and rare blossom. Doing what, as far as I can tell, they always do. Eating, cutting the leaves, slicing small holes in them, chewing, swallowing (digesting, defecating), and they were screwing. Beetle on beetle. Their golden backs gleaming in the hot midday sun. Screwing on every leaf, male mounted firmly and to all appearances permanently on female, no wild mammalian humping, just this golden connection, beetle on beetle by beetle on beetle by beetles and beetles and beetles.

I have never had such an awareness of sex before. I have never (consciously) been in the presence of such a massive orgy before. A wide level field, a meadow of tall still grasses, stippled and studded with bright beetles, silent, unmoving, doing it.

My first response was laughter. In tune with my earlier thoughts of publication, I thought of a book title: von Frisch could have his Dancing Bees; I would sell rings around him with my Balling Beetles!

I leaned closer to one weed, some common plant with broad dull leaves, bearing no name that I knew but carrying a full load of orgiastic beetles. One leaf held fully seven pairs in silent ecstacy. I peered closely at it, wishing that I had Collembola here to explain the parts, the processes I was observing. Almost unconsciously I felt my way through that visual connection into one of those pairs of beetles, into the male hanging on the female's steady back.

And suddenly I felt the most overwhelming, explosive, shattering feeling of my entire life. I literally staggered back, fell onto the ground. From my ninth (?) year on, I have experienced literally countless orgasms, with and without partners, asleep and awake. All men have. But never had I experienced anything like this. I lay back on the ground, my whole body numb, every muscle in my arms and legs fibrillating wildly, an invisible tremble that jangled on and on and on. And I knew that this was the beetle's orgasm, that this blast of sexual fury was going on all around me thousands upon thousands of times, and that this furious orgasm would last not for anguished seconds but ecstatic hours!!

I could not stand it. I rolled over on the weedy ground, dragged myself onto my knees and crawled away, crawled through the high 
itchy weeds, the golden backs of beetles glinting all around me, by my arms and legs, over my head on high wavering stalks.

I finally gained my feet and staggered to the path, ran down it, fell twice to my hands and knees, paused finally here by the bog, seated myself on the flat stone outcropping by the willow where I often settle and write, paused and caught my breath, calmed my nerves, settled my soul.

I was right. This day has given me that. Not to impose myself on nature, but to think myself into it, to join it. To guide it from within. I could have guided even those thousands of beetles, but they caught me by surprise, a sneak attack on my sensibility. But even then, out of control, in a wild nose dive, I found my answers and the clue to my rewards. The rewards are enormous. I still cannot fully face them. I can't bring myself even now to write the whole of what I felt in that field. No man alive (possibly no man who has ever lived) has ever felt a tenth, a hundredth, a millionth of what I have felt. No Casanova, no liver of secret lives. I was a god incarnate; I was more than a god, I was a world, a universe, the cosmos.

Sitting in the combed pebbles, the smooth warm white and tan stones spread over the patio behind the central building at ITS, crouched like a yogi, cross legged, in a pool of light, yellow light from a yellow study spilling out into the moonlight, mingling on these stones, on me, my blue clothes almost green, on this open notebook-the moon round and almost full (tomorrow, full), pale and pure. Love. I love the moon, each stone, each particle, each wave of light, the notebook, the pen, every vibrating cell in my body, in the night, in the world.

Don't dare go in, leave this night, the ecstasy which still fills me. I am literally trembling, trembling from head to toe. I think I understand for the first time McTaggart's contention that (I have it memorized, no need to go to Austin's study and the black books there) "when love reached or passed a certain point, it would be more good than any possible amount of knowledge, virtue, pleasure, or fullness of life could be." More good. More good.

I am in love. I could hump the moon. I finally understand the odd behavior of pet dogs, how sometimes they go mad and hump everything, other dogs, cats, human feet, chairs, everything. Not mad. Not mad. In love. Loving.

I can't believe it. My nerves are still in full spasm. I am full and 
emptying at once. I want the trees, the buildings, every frog in the bog, the moon, the stars. I want to hug the earth, the whole earth. I want to fuck the world.

Feel foolish. Want to stop. Want desperately to go on. Am outside the dormitory building. Her light is on. One shadow on the blind. Alone. The moon is swollen, glowing in this hazy sky. The ground, the hard earth, is like a dream. I am going in. I will surrender. I will be firm. Am going in.

I have been running all night, down the hill and into the trees. Into trees themselves. I have a cut on my forehead somewhere. It has stopped bleeding now. Maybe oozing, but not running wet down over my eyes. I can see. The dawn has come and caught me down and done for. Sitting by the bog. Trying to write it all down. The come-down. The fall.

I knocked on Sara Band's door. Pale green door, like mine, like everyone's. She opened it, dressed in her usual green pants suit, shiny and clean, her red hair, green eyes, pale face. No make up. No surprise.

"I've been expecting you, Cosmo," she said, stepping back to let me enter. "Wondering when you'd drop by."

I may have said something, thought something. All I remember is walking in, turbid with stirred emotions, shaking like a loose roof in a storm.

I heard her click the door shut behind me, heard her say, no mockery in her voice, something else, "Come to give me a Big Time?" I turned to her. "Or maybe another Bit-O-Honey?"

I felt my hips tug forward, tauten of their own volition. I looked for the cold green of her eyes, but their pupils were swollen, the eyes full and dark and black and deep. I reached out for the ice of her touch, took her shoulders, the cool nylon of her suit, drew her to me (or did she draw me to her), was kissing her lips. They were not cold, were hot and moist and opening.

She stepped away, unzipped her jumpsuit, pulled it back from her chest, tiny breasts, huge nipples. How can I write this without falling into the language of cheap sex, into pornography? I don't know that I can. Could anyone?

I remember this: my surprise at her nakedness, my surprise at how she did not seem to care whether I was clothed or bare, even my jacket still on, my surprise at how hot her body was, at how quickly she had 
manipulated me into her, at how smooth and firm her skin was, hard body, grinding at me, holding me down when I struggled to pull away, to gain control.

We lay on the floor, turning and turned. She moaned, a long low cry, not a moan, a sound, a cry, a call. I tried to focus my eyes on her face. All I could see was green, a reflection in the moisture of her face of those cool walls, pale green and those enormous black eyes, like buttons, those huge black eyes looking at me, turning to me, looking at me.

She pulled my head to her; making that low low sound, twisted it around and began to nibble, to chew on my ear, her mouth wet and the sharp teeth, biting my ear, my head.

I struggled to escape. She gnawed at my head. I fought. I hit at her. I punched at her stomach. I threw myself back and away from her. I felt no more sexual pressure, not even release of pressure. Only fear of those huge hungry black eyes.

I ran away, ran out of that room, down that long hall, out of that building, down the hill. Battering from tree to bush to tree. Splashing the edges of the bog. Battling my way under the moon, away from the melting moon, into the trees. Finally here. The sun stealing up on me. I can't stand it any more. Must get on, get away.

I am in the bog. I am calm, writing this down so that I can throw it, if need be, to the shore, an agonizingly few feet away. I am calm. I am in the bog. Quicksand. It is sucking me down. I struggled against it for a while, but now I am calm. I am writing this to help me wait for someone to come this way, to pull me out. There are plenty of fallen tree limbs about. I can see five or six. Six. I can see six from here. I am on my back. My feet are gone. But from the knees up, I am still relatively free. I don't seem to sink much so long as I don't move too much. I ran right into the bog. The first thing I knew was that I heard the frogs squeaking and plopping. Are there snakes here? I am in the bog.

I will will myself free, impose my will on the very molecules of this bog. I will start slowly, focus on the water and scum until they become solid as muscle and skin. I will flex them then like an arm, push myself up and out like the contents of a swollen pimple! It will work! It will work! 
Why am I hung here? Not floating like a vessel on the stream of time, but bogged down, half earth already? My head aches with the force of my thinking. This scummy, this goddamned bog lies here, this ooze, this stinking goddamn ooze. Why isn't it solid? Contact! Contact! Who are we? Where are we?

Sinking. Surrendered. Poor Moe, betrayed hound, Dark's sunk dog, brother in name and flesh. I was going to raise your bones, make them clatter across the surface of this bog like you doubtless once skittered, all comic toenails and eager motion, across the kitchen floor or waxed hallway. Poor dog. I've come, am coming to join you, a set of old bones, frog food, in the slimy bottom of this bottomless bog. No hope. No one is coming here. I will never know what I could have done. What Austin wrote in his copy of my book. Who Sara Band really is. The rain and fog will ruin even this notebook, pulp it back into the mushy ground from whence it came. No way to win in this mindless mess. No way.

Sunk deeper in, half in. It is pleasant now, the warm bog water still, silent. It holds me like a mother. I am floating like a sigh, an unfocussed memory easing down in amniotic delight. Mindless. Wordless. Content.

Do I know what it is to love others? Did I ever know McTaggart, understand him, feel him? To love others. To reverence myself for loving them.

I am holding to solid things now. To Juan Cortapiedras. To Hector Collembola. To Sara Band. Yes, to Sara Band, neither cold nor hot, just Sara Band, slow time, soft fact, hard truth. The walls of ITS. These trees guarding my blue sinking self from the hazy yellow sun. The even surface of this deadly bog, green shading to dark green shading to brown. The frogs bulging their steady ways along under its surface. The birds skipping the green flat surface, beaks open for bugs, for death, for life.

Something stirred in the weeds on the shore. My heart jumped for a second like a startled frog. Whatever it was, groundhog, fox, weary small hound, it went away.

I am holding to solid things, their being there enough, letting them be, being there and here.

This is all so absurd. Not philosophically. Simply silly. I am eating a Zero bar, last thing in my pockets, living for a short time longer on the last paper-wrapped remnants of my ridiculous past. 
Oddly enough I am not drawn back to my past. A drowning man, I am not reliving my life. No need. It's done. And the world is still here. The trees are buzzing with life, insects sawing the rhythm of the spheres. Mayflies skimming the damp air, the moving light. That is enough.

I am sunk too deeply now even for help to help.

What strength I have's mine own.

Myself. My self. Do I survive in others' minds? In Sara Band's? In her anger, her laughter, her scorn?

Remember Broad's saying once that a human being is a long event. My long event grows shorter. The world within, without. The sun has crossed the treetops, is sinking, too.

My mind has returned to me, has reached out into the world around me, this bog, this sinking. I do know now what I missed all along. I am sharing all this life, second by long second, brief moment. My event is long, long as all men, all memory, long as the world, as all time. My flowing is that larger flowing; my stillness is that larger calm.

This living world did not need my mind. It had it all along. Yours, too. All of us. Self and self and self, infinite, endless, immortal. Self and self.

Am nearly under. Back first. Will soon be breathing bog. Must toss this book ashore. Am floating in a music of blood, yellow light, a harmony of cells singing. Cosmo Cotswaldo joins the cosmos.

As if he'd ever been away.

I am walking on water. I am sinking in sand. In either case, both cases, I shall, late or soon, be swimming in air. 